\title{
The state of mountain forest ecosystems in the Bashkir Nature Reserve (Southern Urals)
}

\author{
Ainur Biembetov*, Nur Yanybayev, and Ilnar Valiev \\ Bashkir State Nature Reserve, 453580, Karat str., 2, Starosubkhangulovo village, Burzyansky district, Republic of \\ Bashkortostan, Russia
}

\begin{abstract}
Environmental monitoring of specially protected natural reservations in Russia makes it necessary to analyze periodically the parameters of natural reservations to identify the state of components of nature. The Bashkir Nature Reserve is located in the Southern Urals. The availability of materials on forest management in 1956, 1969, 1979, and 2016 is one of the special features of the scientific fund of the Bashkir Nature Reserve. The analysis of these materials showed stable positive dynamics of the development of coniferous and small-leaved deciduous forestry and its current state.
\end{abstract}

\section{Introduction}

In recent years, an analysis of the available information about the processes occurring in natural communities is necessary due to the increased frequency of natural disasters. It is especially important to pay attention to the ecological state of mountain forests as the most vulnerable biocenoses.

The purpose of this study is to determine the state and dynamics of mountain forest ecosystems in the Bashkir Nature Reserve (Southern Urals), taking into account the main forest management indicators for 60 years.

\section{General characteristics of the reserve}

The Bashkir State Nature Reserve Forestry is a specially protected natural area (SPNA). It has a special environmental, scientific, cultural, aesthetic, and recreational significance. This unique area of the South Ural nature was withdrawn from economic use by decisions of state authorities. The reserve has a special protection regime.

The mountain forests of the Bashkir Nature Reserve are classified as a protected category and have a special protection status. These forests have a significant role as a regulator of surface water runoff and a factor contributing to water seepage into the soil.

The territory of the reserve is geographically assigned to the central mountainous region of the Southern Urals (Fig.1).

The territory is represented by a compact forest area with a length of $23 \mathrm{~km}$ (from north to south), and $31 \mathrm{~km}$ (from east to west). The geographical location of the forestry is determined by the coordinates:

- from north to south between $53^{\circ} 30^{\prime}$ and $53^{\circ} 15^{\prime}$ northern latitude,
- from west to east between $57^{\circ} 43^{\prime}$ and $58^{\circ} 11^{\prime}$ eastern longitude.

It can be divided into two sharply different parts: the western one, represented by the strongly dissected Southern Kraka massifs, and the eastern one with the subdued relief of the Ural-Tau ridge. The topographic elevation data of the Southern Kraka massif is 700-929 $\mathrm{m}$, the Ural-Tau ridge is $800-943 \mathrm{~m}$ above sea level. There is an extensive depression zone $(500-650 \mathrm{~m})$ between these geological objects.

Geologically, the Ural-Tau ridge is composed of the oldest rocks (gneiss, quartzite, various highly metamorphosed crystalline shales). The area of the Southern Kraka massif is represented by siliceous shales, quartzitic sandstones. In some places, there are horizons of limestone and tuff.

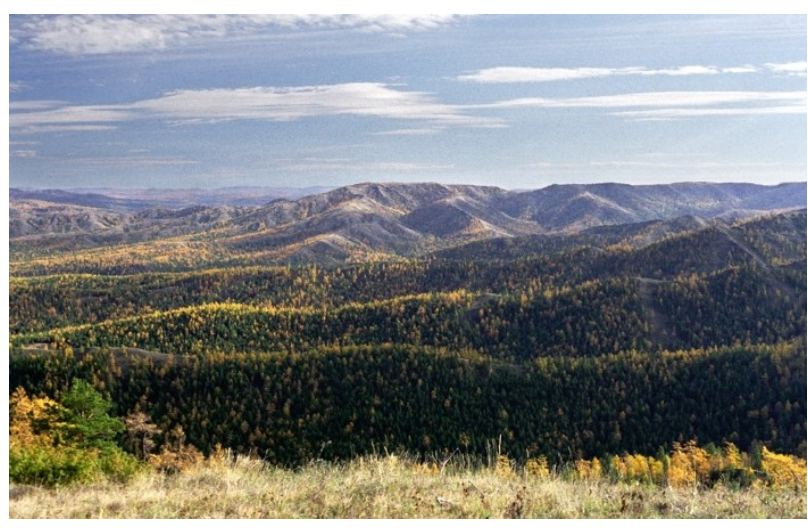

Fig. 1. General view of the Bashkir Nature Reserve (Southern Urals).

All forests of the Bashkir State Nature Reserve forestry are classified as protected forests according to article 10 (part 2) of the Forest Code of the Russian Federation (Federal Law No. 200-FZ /4/ of 04.12.2006).

\footnotetext{
*Corresponding author: biembetov@mail.ru
} 
The reserve forest stands are located on SPNA with a special forestry regime aimed at maximum preservation of natural objects in the natural state (in accordance with paragraph 19 of the Forest Management Instruction approved by the order of the Forestry Agency of Russian Federation No.516 of 12.12.2011 and with articles 102 (part 2) and 103 (part 1) of the Forest Code of the Russian Federation).

Protected forests exist in order to preserve the environment, water protection, protective, sanitaryhygienic, health-improving and other functions. Forest stands can be used provided that this use is compatible with the purpose of these forests and their useful functions.

The Bashkir State Nature Reserve forestry has a special regime for forest protection and forestry management by its status and type in regulatory documents (concerning SPNA). The regime is defined by the Land Code of the Russian Federation, the Forest Code of the Russian Federation, Federal Law No. 33, as well as regulatory legal acts of the subject of the Russian Federation and the Republic of Bashkortostan. The specifics of the use, protection, and reproduction of forests in the Bashkir State Nature Reserve are defined by the Order of the Ministry of Natural Resources No. $181 / 21 /$.

\section{Analysis of forest stands parameters}

As of January 2016, there are 28946.5 ha $(68.8 \%)$ of coniferous-dominated forest in planted area and 7342.9 thousand $\mathrm{m}^{3}(73.5 \%)$ in volume, 13140.2 ha $(31.2 \%)$ of small-leaved forest in planted area and 2640.9 thousand $\mathrm{m}^{3}(26.5 \%)$ in volume in the Bashkir Nature State Reserve forestry (Table 1, 2).

At present, ripe and overripe plantings predominate by age structure and make up $57.1 \%$ of the lands covered with forest vegetation (including overripe - 29.1\%), ripening stand $-25.0 \%$, middle-aged $-17.0 \%$, young stand is practically absent and occupy only $0.9 \%$ of the area. Young trees were formed on burnt areas after large forest fires in 1975. The main predominant species of forestry are European red pine $(25570.1$ ha $-60.8 \%)$ and European white birch (10350.7 ha - 24.6\%).

Forest capacity is characterized by a fairly high growth class (bonitet) -2.8 . Forest stands of I-II growth classes make up $37.2 \%$ of the forest area, III-IV growth classes $-61.3 \%, \mathrm{~V}-\mathrm{Vb}$ growth classes $-1.5 \%$.

Siberian larch and Grey alder plantations of natural origin have low forest capacity. European red pine, European white birch and aspen plantations have high capacity.

The average stand density is 0.70 . Low-stand density plantings (0.3-0.4) occupy $6.6 \%$, medium-stand density $(0.5-0.7)-54.2 \%$ and high-stand density (0.8-1.0) $39.2 \%$ of the lands covered with forest vegetation (at that $73.5 \%$ of forests are coniferous plantations). The average stand density of coniferous stands is 0.70 , small-leaved 0.69 .
There are no signs of mass degradation and drying of trees in the forest area, thus, the forest stands are classified as Class I by biological resistance (according to the classification of the Moscow Forestry Institute). The forest stands are classified as Class II by the degree of resistance to negative anthropogenic influences. Therefore, forest tending is not planned.

Table 1. The main parameters of forest stands by trees species in the Bashkir Nature Reserve (1956-2016)

\begin{tabular}{|c|c|c|c|c|}
\hline $\begin{array}{c}\text { Predomin } \\
\text { ant } \\
\text { species }\end{array}$ & Area, ha & $\begin{array}{c}\text { Ripe and } \\
\text { overripe, } \\
\text { ha }\end{array}$ & $\begin{array}{c}\text { Middle } \\
\text { aged }\end{array}$ & $\begin{array}{c}\text { Growth } \\
\text { class }\end{array}$ \\
\hline
\end{tabular}

European red pine (Pinus sylvestris)

\begin{tabular}{|c|c|c|c|c|}
\hline $1956[2]$ & 21913 & 8347 & 66 & II,8 \\
\hline $1969[3]$ & 24884 & 1585 & 73 & II,7 \\
\hline $1979[4]$ & 24426 & 911 & 77 & II,3 \\
\hline $2016[5]$ & 25570,1 & 7441 & 110 & II,8 \\
\hline
\end{tabular}

Siberian larch (Larix sibirica)

\begin{tabular}{|c|c|c|c|c|}
\hline $1956[2]$ & 4211 & 3834 & 140 & IV,1 \\
\hline $1969[3]$ & 2443 & 1321 & 137 & IV,0 \\
\hline $1979[4]$ & 3240 & 1460 & 124 & III,5 \\
\hline $2016[5]$ & 3376,4 & 983 & 155 & III,5 \\
\hline
\end{tabular}

European white birch (Betula pendula)

\begin{tabular}{|c|c|c|c|c|}
\hline $1956[2]$ & 19076 & 12321 & 56 & II,9 \\
\hline $1969[3]$ & 12903 & 1198 & 60 & III,1 \\
\hline $1979[4]$ & 10384 & 4496 & 72 & II,9 \\
\hline $2016[5]$ & 10350,7 & 3012 & 101 & III,1 \\
\hline
\end{tabular}

Aspen (Populus tremula)

\begin{tabular}{|c|c|c|c|c|}
\hline $1956[2]$ & 2987 & 2323 & 59 & II,9 \\
\hline $1969[3]$ & 2400 & 4446 & 67 & III,0 \\
\hline $1979[4]$ & 2569 & 5085 & 75 & III,0 \\
\hline $2016[5]$ & 2326,7 & - & 105 & - \\
\hline
\end{tabular}

Grey alder (Alnus incana)

\begin{tabular}{|c|c|c|c|c|}
\hline $1956[2]$ & 279 & - & 27 & IV, 4 \\
\hline $1969[3]$ & 252 & 3 & 42 & IV,1 \\
\hline
\end{tabular}




\begin{tabular}{|c|c|c|c|c|}
\hline $1979[4]$ & 440 & 26 & 50 & IV,3 \\
\hline $2016[5]$ & 462,8 & - & 35 & - \\
\hline
\end{tabular}

Table 2. Total and average standing volume of forest stands by trees species in the Bashkir Nature Reserve (1956-2016)

\begin{tabular}{|c|c|}
\hline $\begin{array}{l}\text { Total standing volume, } \\
\qquad \mathrm{m}^{3}\end{array}$ & $\begin{array}{l}\text { Average standing volume, } \\
\qquad \mathrm{m}^{3} / \mathrm{ha}\end{array}$ \\
\hline \multicolumn{2}{|c|}{ European red pine (Pinus sylvestris) } \\
\hline 3566 & 132 \\
\hline 4373 & 109 \\
\hline 5593 & - \\
\hline 6776 & 265 \\
\hline \multicolumn{2}{|c|}{ Siberian larch (Larix sibirica) } \\
\hline 439 & 106 \\
\hline 274 & 105 \\
\hline 556 & - \\
\hline 570 & 169 \\
\hline \multicolumn{2}{|c|}{ European white birch (Betula pendula) } \\
\hline 2478,5 & 149 \\
\hline 2324 & 140 \\
\hline 2361 & 200 \\
\hline 2070,1 & - \\
\hline \multicolumn{2}{|l|}{ Aspen (Populus tremula) } \\
\hline 424,2 & 158 \\
\hline 396 & - \\
\hline- & - \\
\hline 549,1 & 236 \\
\hline \multicolumn{2}{|l|}{ Grey alder (Alnus incana) } \\
\hline 8,6 & - \\
\hline 7,7 & - \\
\hline- & - \\
\hline 23 & 50 \\
\hline
\end{tabular}

The analysis of the main parameters of SPNA woodlands showed:

From 1929 to 1951 , this territory was a specially protected natural territory. It was created "for the purpose of preserving in an inviolable form for the scientific study of the laws of nature development of the Southern Urals with its characteristic flora and fauna, as well as the associated study of the forests of the Bashkir Autonomous Soviet Socialist Republic" [6].
From 1951 to 1957 , the territory of the Bashkir Reserve in the former borders was transformed into the Yuzhno-Uzyansky forestry.

In 1957, this mountain-forest territory was transferred to a SPNA with a protected regime in the former unchanged borders.

An analysis of the forestry development with periodic forest management works shows that the composition of tree species has remained unchanged in this natural area. Coniferous species (about $80 \%$ ) occupy a large area of the reserve territory and have a stable positive dynamic for 60 years (Table 3 ).

The predominant species of the reserve is European red pine (Fig. 2). The total coniferous standing volume has doubled (Table 4). A slight decrease in the larch standing volume in the middle of the 20th century can be explained by technical errors during forest management works on this territory.

Table 3. Dynamics of the area of coniferous and small-leaved forestry in the Bashkir Nature Reserve, ha

\begin{tabular}{|c|c|c|c|c|}
\hline \multirow{2}{*}{ Forestry } & \multicolumn{4}{|c|}{ Years } \\
\cline { 2 - 5 } & $1956[2]$ & $1969[3]$ & $1979[4]$ & $2016[5]$ \\
\hline Coniferous & 26124 & 27327 & 27666 & 28947 \\
\hline $\begin{array}{c}\text { Small- } \\
\text { leaved }\end{array}$ & 22342 & 15555 & 13393 & 13140 \\
\hline
\end{tabular}

Table 4. The main taxational specifications of the forest area in the Bashkir Nature Reserve

\begin{tabular}{|c|c|c|c|}
\hline Years & Middle age & $\begin{array}{c}\text { Total standing } \\
\text { volume, } \\
\mathrm{m}^{3}\end{array}$ & $\begin{array}{c}\text { Average standing } \\
\text { volume, } \mathrm{m}^{3} / \mathrm{ha}\end{array}$ \\
\hline \multicolumn{4}{|c|}{ Coniferous } \\
\hline $1956[2]$ & 75 & 3566 & 120 \\
\hline $2016[5]$ & 115 & 7342 & 254 \\
\hline & & Small-leaved \\
\hline $1956[2]$ & 53 & 432,8 & 153 \\
\hline $2016[5]$ & 99 & 2640 & 201 \\
\hline
\end{tabular}




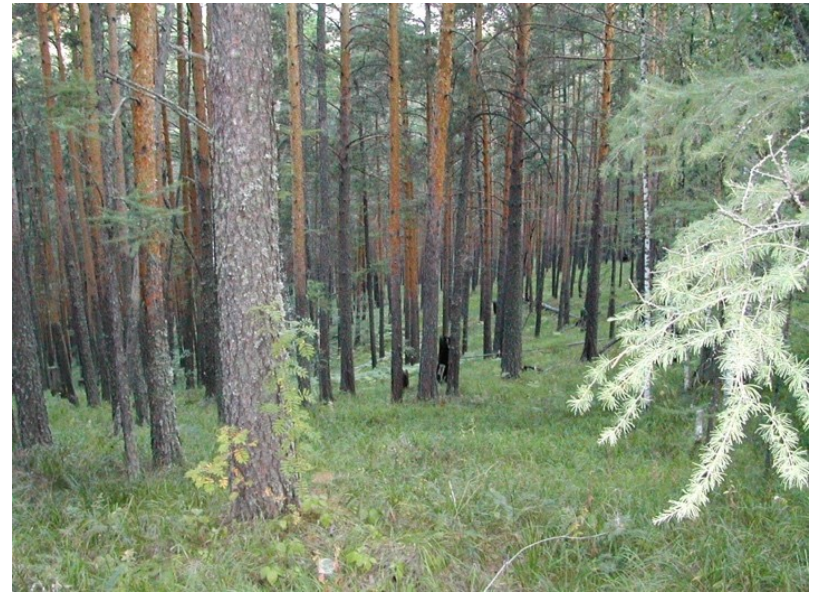

Fig. 2. Stand of European red pine in the Bashkir Nature Reserve (Southern Urals)

The analysis of small-leaved woodlands shows a negative trend, which indicates a good regenerative succession of pine as the indigenous species. The average age of European white birch as the main species of small-leaved forest stands has increased by 46 years over the past 60 years. The indicators of the total and average standing volume of birch have also increased.

Moreover, the analysis of the dynamics of the number of forest pests was carried out on the basis of available materials in the scientific fund of the Bashkir Nature Reserve for the last 90 years. The analysis showed that stand of European red pine is periodically weakened due to the sharp reproduction of xylophages [7].

\section{Conclusion}

To date, the Bashkir State Nature Reserve has a stable positive dynamic of the coniferous and small-leaved forestland development. There is a good regenerative succession of indigenous species (European red pine and Siberian larch) in the forest stands.

\section{References}

1. Resolution of the BSNK (Bashsovnarkom) "On the establishment of the Bashkir State Reserve", 26/4. (UFA, VNII L/S, 1930)

2. M. Kapura, V. Popov, et al., Organizational and economic plan for the Yuzhno-Uzyansky forestry of the Bashkir administration. Forest management 1955-1956, Ryazan expedition "Lesproekt", 1, 1 (Ryazan, 1956)

3. P. Lesnov, A. Krestyanov, et al., The project of organization and management of forestry of the Bashkir State Reserve. Forest management 1969, Bashkir aerial forestry expedition of the Volga forest management enterprise "Lesproekt", 1, 183 (Ufa, 1970)
4. P. Lesnov, V. Sidorenko, et al., The project of organization and development of forestry of the Bashkir State Reserve. Explanatory note. 1st Gorky forest management expedition 1979-1980. Volga Forest Management Enterprise, 1, 193 (1980)

5. R. Akhmetov, F. Bazhaev, Forest development project of the forestry "Bashkir State Nature Reserve", 209 (Ufa, 2016)

6. S. Severtsev, Report on the Bashkir Reserve. Journal No. 26 of the meeting of the Council of People's Commissars of the Bashkir ASSR (Ufa, 1930)

7. V. Yanybaeva Sustainable development of territories: theory and practice (Sibay Information Center-branch of the State Unitary Enterprise of the Republic of Bashkortostan, Sibay, 2020). 